\title{
LIFE Lech - Dynamic River System Lech
}

\author{
Marlene Salchner
}

Keywords: LIFE Project, Natura 2000 area, Tiroler Lech Nature Park, wild river, natural dynamic of the river

\section{Abstract}

Two at one stroke - the LIFE Lech project combines species and flood protection. The project, which will run for 5 years and is financed with EU subsidies, focuses on large gravel banks and wild river habitats. River engineering measures are being implemented to promote these habitats. Rare and endangered plant and animal species are also being helped with targeted species protection measures. This work is accompanied by an extensive monitoring programme and a wide range of public relations projects.
Profile

Protected area

Tiroler Lech Nature

Park

Mountain range

\section{Introduction}

Following earlier LIFE projects, the European Commission has again approved a LIFE project in the Lech Valley. More than 6 million euros are available until 2021 for the revitalization of the Lech. $60 \%$ of this comes from EU LIFE funding. The LIFE Lech project aims to link species protection and flood prevention in the best possible ways. It is particularly concerned with the preservation or restoration of wild river habitats and their typical biodiversity. Between 2016 and 2021, 12 river revitalization measures will be implemented on the Tiroler Lech. At suitable locations, bank protection structures and stone groynes that are no longer needed will be removed so that the Lech can deposit stones there again, and gravel and sandbanks can form, thus creating habitats for rare and endangered animal and plant species, such as the Stone Crayfish (Austropotamobius torrentium), Dwarf Bulrush (Typha minima) or the German Tamarisk (Myricaria germanica), which need special support in the Tiroler Lech Nature Park. To ensure their survival, the LIFE Project focuses on special species protection measures.

\section{The Tiroler Lech Nature Park}

The unique wild river landscape on the Tiroler Lech (see Figure 1), together with its tributaries, is one of the last near-natural Alpine river valleys in Austria, and the last wild river landscape in the northern $\mathrm{Al}$ pine region. The Tiroler Lech Nature Park in its entirety is a Natura 2000 area and a nature reserve. In 2004 the area received the label Nature Park from the federal government of Tyrol.

Many protected areas in Tyrol are located in the mountains, away from inhabited areas. The Tiroler Lech Nature Park is different: the Lech together with its small tributaries forms the largest continuous protected area in the valley area of Tyrol. This extensive valley location is a special feature, because the areas of

\section{Alps, Austria}

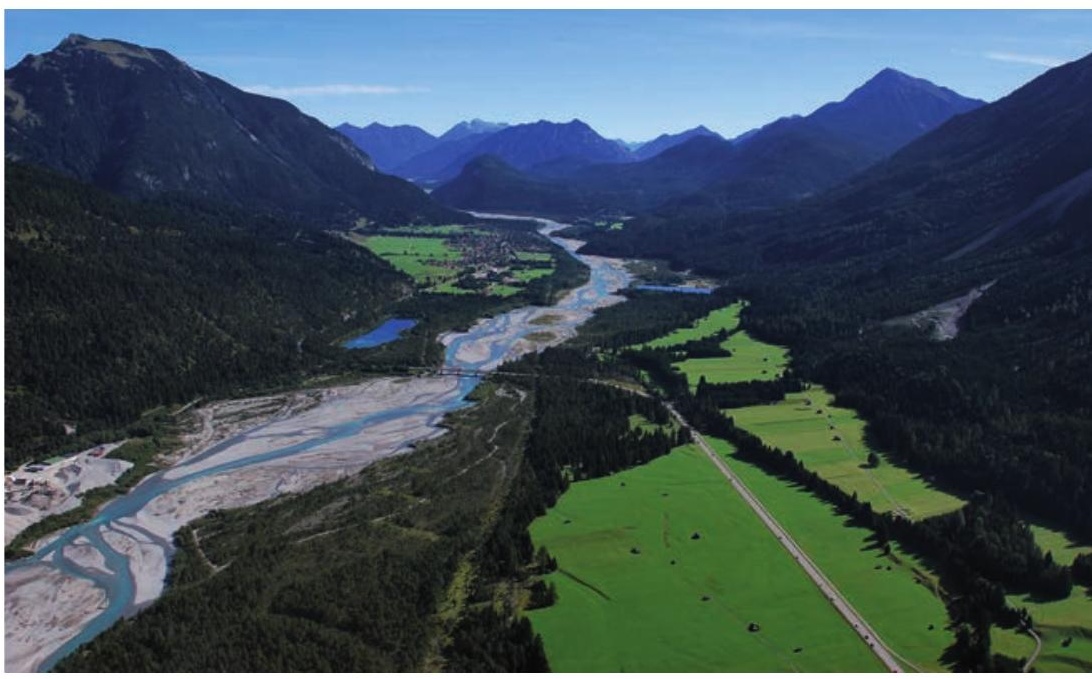

Figure 1 - The river Lech (C) Mario Posch

economic activity and permanent human settlements along the Tiroler Lech border directly on the areas that are important for natural history.

\section{The heart of the Tiroler Lech Nature Park}

The Tiroler Lech is the last near-natural river in the Northern Alps. Large sand and gravel banks, wide alluvial forest areas and shimmering, light turquoise-blue water give the Tiroler Lech its special beauty. The Lech flows through Tyrol for approximately $60 \mathrm{~km}$. Characteristic is the river's braiding which creates islands of sand and gravel, and the wide riverbed, which is over $100 \mathrm{~m}$ wide in some places. The interaction of water, scree, stones, gravel and sand, the gradient of the riverbed and the speed of the water play decisive roles in the constant remodelling of the wild river. The Lech has two faces - wild or tame, thundering through the valley or gently branching, with much or little water. All this brings about constant changes. This dynamic is characteristic of a wild river. 

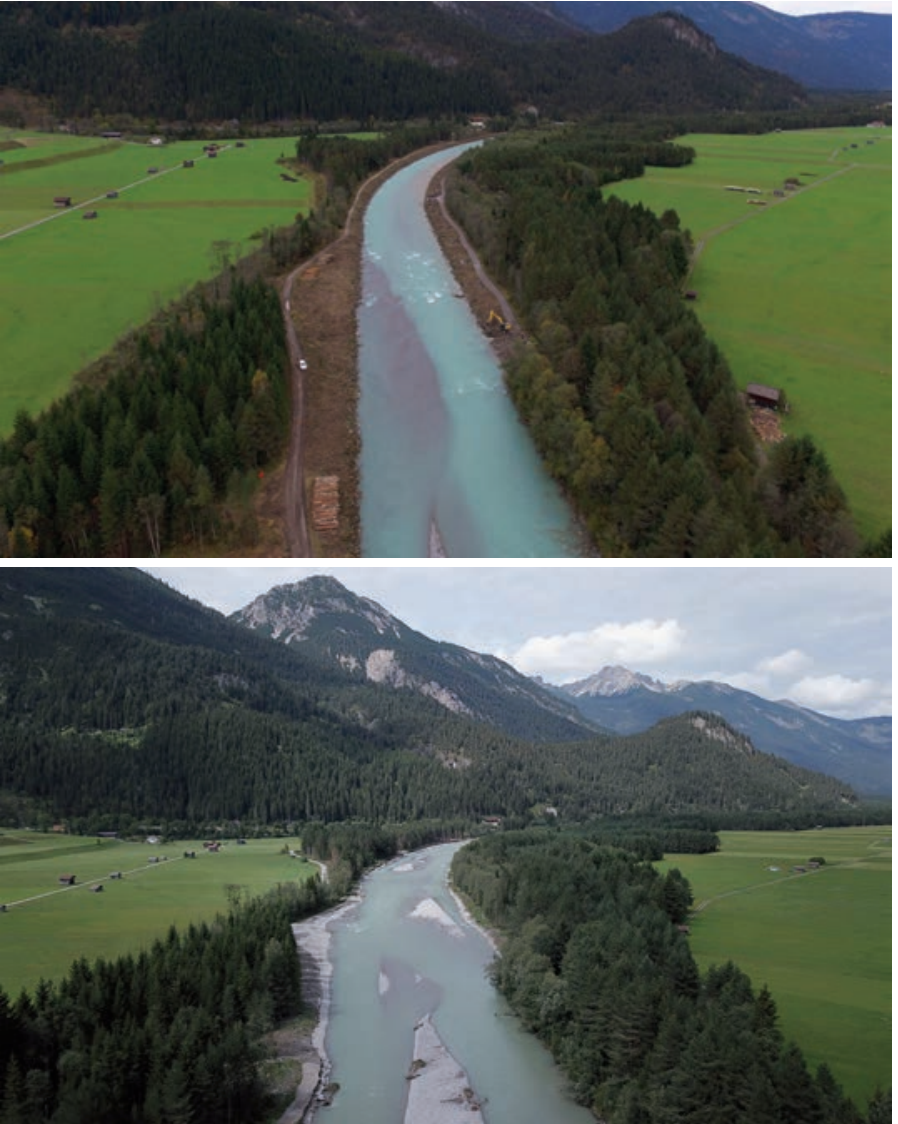

Figure 2 - Top: before restoration, bottom: after restoration. (C) Baubezirksamt Reutte

\section{Building with consequences}

The large-scale hydraulic engineering began at the beginning of the $20^{\text {th }}$ century, after a catastrophic event in 1910 devastated large parts of the valley floor and destroyed property. The cause of this catastrophe was not least the unplanned clearing of the protection forests.

Large stretches of the Lech were channelled according to the state of the art and knowledge of the time: transverse structures (groynes) were built, behind which gravel accumulated. Longitudinal structures were then built along the river, between the groynes. In this way, the river was channelled, its flow increased in speed, and sediment was removed from

Infobox - Nature Park

\section{Area: $41.38 \mathrm{~km}^{2}$}

Length: $65 \mathrm{~km}$

Protection categories: Natura 2000 site, nature reserve, protected landscape area, natural monument

Nature park region:

24 communities from Steeg to Vils

- Last wild river landscape of the Northern Alps

Power of river to constantly remodel its course and sand/gravel banks

Wide riverbed with sand and gravel banks

Rare and endangered animal and plant species the riverbed, which thus became deeper. Over time, the engineering of the river created land that became used for agriculture and settlement (Figure 2).

These hydraulic structures, built by several generations of Lechtalers during the winter months for a meagre additional income, still characterize the landscape of the Tiroler Lech in some sections today.

In addition, around 1960, bedload barriers were built into the Streim, Schwarzwasser and Hornbach valleys to retain the stones in these tributaries.

Not without consequences! The Lech's riverbed deepened further and the groundwater level lowered. The plant and animal specialists of the wild river landscape and the adjacent habitats, which depend on regular flooding, were and still are affected by this.

During the following decades, hydraulic engineers realized that the Lech needed the bedload (rock material) from the tributaries to line and stabilize its riverbed with. The bedload barriers erected earlier therefore proved to be more of a curse than a blessing. From 2001 to 2007, the Natura 2000 area of the Tiroler Lech was already the scene of a LIFE project (Tiroler Lech - Wild river landscape of the Tiroler Lech 2020, LIFE00 NAT/A/007053), in which the first positive steps were taken to redynamize the river and the surrounding habitats (Figure 2).

\section{The LIFE Lech Project}

Extensive gravel banks and intact wild river sections characterize the Tiroler Lech where it forms the border with Germany. Such ecosystems are among the most threatened landscape types in Central Europe. Preserving the natural dynamics of the river and its adjacent riparian forests (Figure 3) with their typical plant and animal species is the overall objective of the LIFE Lech project. Special attention is paid to the dynamically formed gravel bank areas and pioneer sites (Figure 4).

In order to restore or improve the natural dynamics of the river, river engineering works will be implemented. The highly specialized and endangered wild river species are promoted and cared for in the best possible way by means of monitoring and species protection measures. The focus of LIFE Lech activities is on the Flora-Fauna Habitats (FFH):

- 3230 - Alpine rivers with riparian woodland of Myricaria germanica,

- 7240 - Alpine pioneer formations of the Caricion bicolorisatrofuscae

- 91E0* - alluvial forests with Alnus glutinosa and Fraxinus excelsior (Alno-Padion, Alnion incanae, Salicion albae).

Other target species are the Common Sandpiper (Actitis hypoleucos), Little Ringed Plover (Charadrius dubius), Bilek's Azure Maiden (Coenagrion hylas), European Bullhead (Cottus gobio), Stone Crayfish (Austropotamobius torrentium) and Northern Crested Newt (Triturus cristatus), see Figure 5. 
All these measures are accompanied by extensive public relations activities.

\section{River engineering measures}

Within the framework of the LIFE Lech project, 12 river engineering measures and various species protection measures are being implemented on the upper reaches of the Tiroler Lech and where the river borders German territory. The measures are particularly suitable for the restoration of dynamic gravel areas and pioneer sites. To restore the natural dynamics of the river, river barriers are removed, the riverbed is widened, tributaries are created, and cross-bracings are shortened (Figure 7). This creates habitats for highly specialized species adapted to the wild river. At the same time, the deepening of the riverbed ceases and the groundwater level is stabilized or raised. This benefits the floodplains, the species that live there, and ultimately mankind in the form of better flood protection.

\section{Example: Revitalization near Stanzach- Vorderhornbach}

The Lech was closely regulated near StanzachVorderhornbach (Figure 2), causing the river to dig a deeper and deeper bed. Now, the old longitudinal structures and groynes have been removed, the riverside path moved inland to a safe distance, and the Lech can shape its own banks again. When water levels are high, the river has more space again, and the further deepening of the riverbed has been stopped.

\section{Example: Revitalization near Stockach}

Downstream from the bridge over the Lech at Stockach, widening the river now provides more space, which benefits nature and local people: the characteristic flora and fauna of the Lech find new habitats; people find recreation on easily accessible banks; the nearby residential and industrial areas are protected by the higher discharge capacity and additional flood barriers.

\section{Species protection measures}

The modifications along the river are designed to promote habitats for numerous specialized and endangered animal and plant species, such as the German Tamarisk (Myricaria germanica), Little Ringed Plover (Charadrius dubius), Bryodemella tuberculata - a species of a grasshopper typical of Northern Alpine regions, or European Bullhead (Cottus gobio).

On the basis of a study of environmental variants, the LIFE Project also implements specific conservation measures for particularly endangered species, such as the Dwarf Bulrush (Typha minima) (Figure 6). This particular species prefers to colonize periodically flooded banks of slow-flowing stretches of the river with sandy-silty subsoil where marsh plants grow. Without the constant modifications to the river's braiding and the displacement of soil, the competition-weak

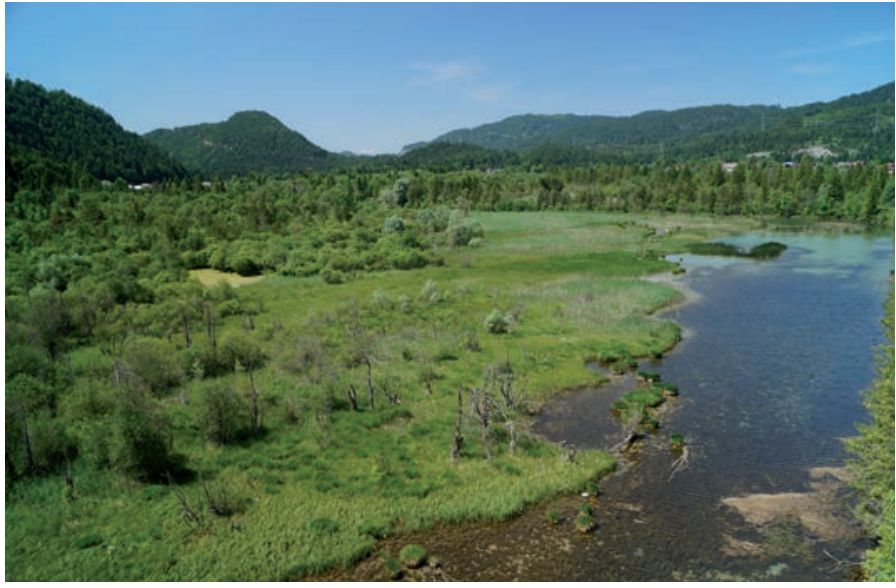

Figure 3-Riparian forest (C) Francesca Wolf

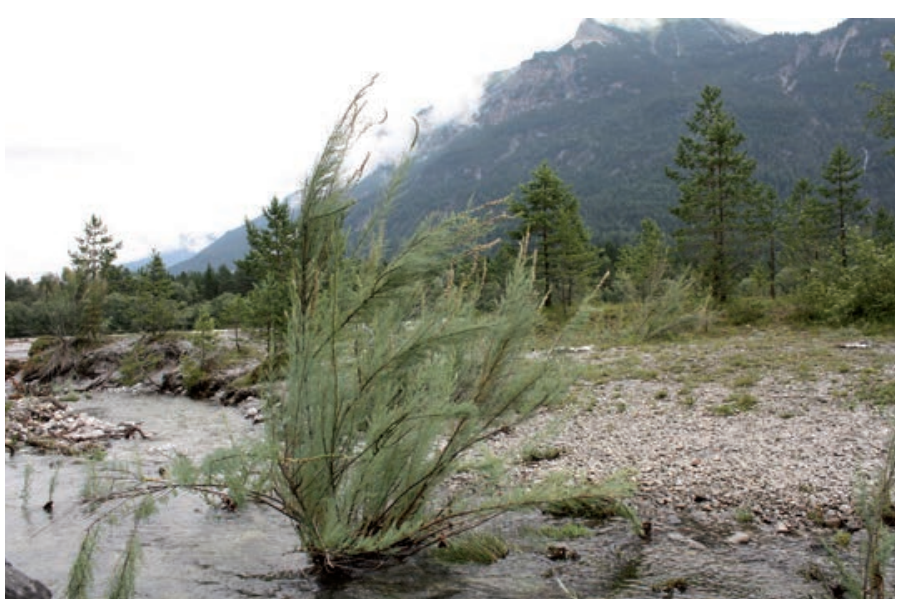

Figure 4 - Dynamically formed gravel bank and pioneer sites with Myricaria germanica. (C) Anette Kestler

and light-loving Dwarf Bulrush would be quickly displaced by taller species such as willows. In the past, there were large populations of Dwarf Bulrush in the river systems in the Alps and Alpine foothills. Dramatic declines of the species due to habitat loss caused by

Infobox - LIFE Lech

Project name: LIFE Lech - Dynamic River System Lech

Project number: LIFE 15 NAT/AT/000167

Project period: 1 September 2016 - 31 December 2021

Project area:

- Natura 2000 site Tiroler Lech

- Natura 2000 site Falkenstein, Alatsee, Faulenbacher \& Lechtal

Natura 2000 area Ammergebirge with Kienberg, Schwarzberg and Falkenstein

Budget: $€ 6093220$

EU funding: 60\% (€ 3655932)

Project Management:

- Federal Water Engineering Administration Tyrol, Building District Office Reutte, Austria

Project partner:

- Office of the Tyrolean Provincial Government, Department of Environmental Protection, Austria

Water Management Office Kempten, Germany 

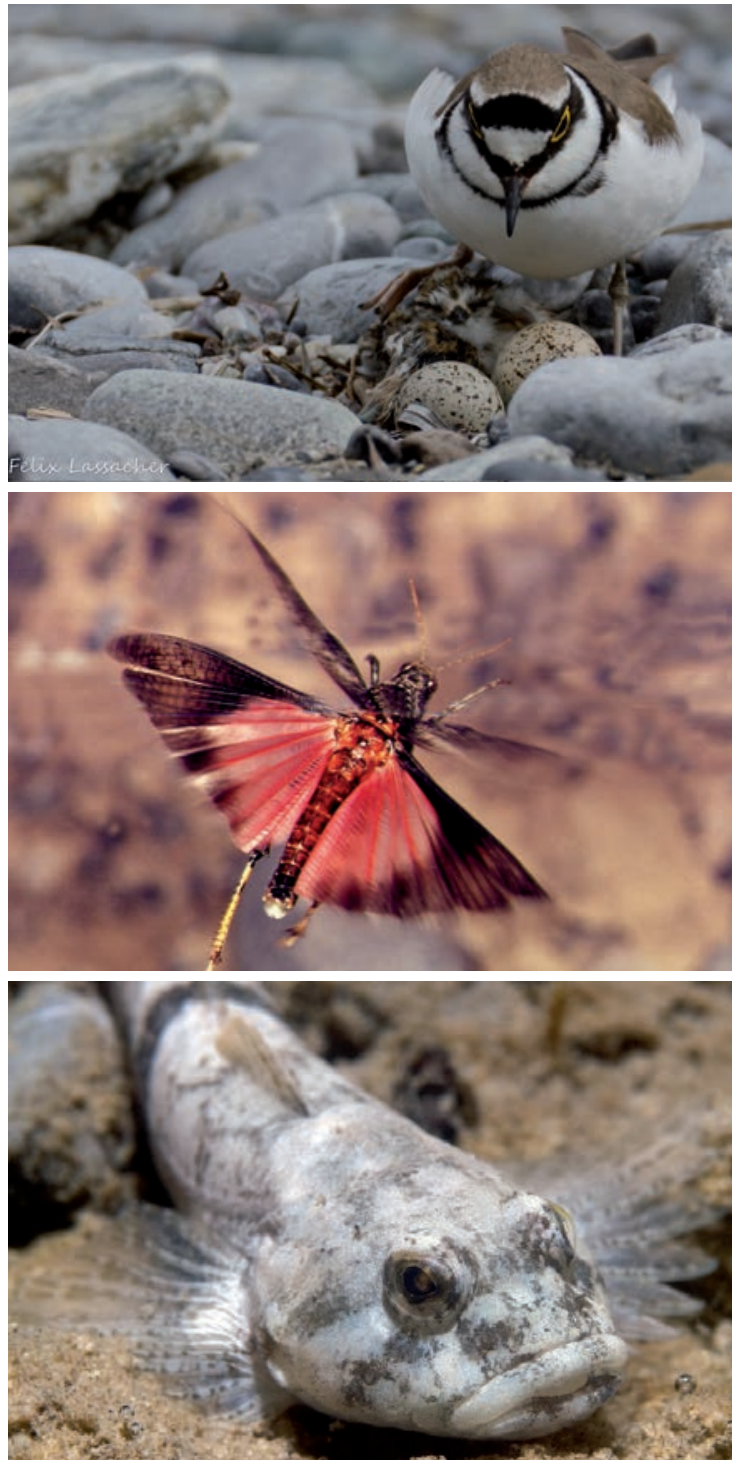

Figure 5 - Top: Charadrius dubius (C) Felix Lassacher, middle: Bryodemella tuberculata (C) Anton Voraner, bottom: Cottus gobio (C) die-nATurknipser

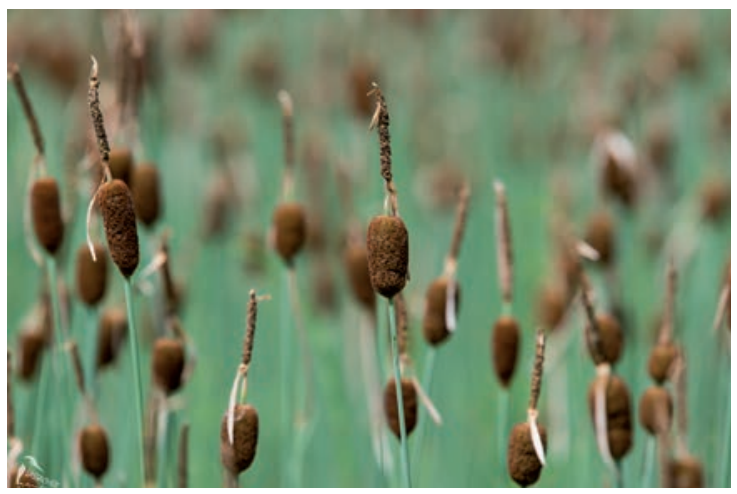

Figure 6 - Typha minima (C) Felix Lassacher

river regulation have been recorded over the last 100 years. Today it is acutely threatened with extinction in the Alpine countries. Isolated remaining populations can still be found on the Tiroler Lech. Austria therefore bears a special responsibility for the conservation of the Dwarf Bulrush in Europe. Within the framework of the LIFE Lech project, young plants of the Dwarf Bulrush cultivated at the University of Innsbruck are being planted in suitable locations.

The Natterjack Toad (Epidalea calamita) is the rarest amphibian in Austria. On the Tiroler Lech, it inhabits biotopes with little or no vegetation that provide sufficient hiding places and small, very shallow pools (for spawning). In order to promote and secure its survival, new spawning grounds are being created for the Natterjack Toad.

The Scarce Heath (Coenonympha hero) is another focus of the project. This protected butterfly can also be found in the Tiroler Lech Nature Park, in sparse woods or pipe grass meadows. In order to support its population, two hectares of forest in Musau, for example, are to be converted into pasture. This could enable a genetic exchange between previously isolated populations and create a large, coherent habitat for the endangered species.

\section{Monitoring}

The success of the revitalization measures is monitored by repeated observation, in the context of which inanimate environmental factors, such as the development of the riverbed, are examined. Other biotic environmental factors, such as the populations of protected species and habitats, are also observed. The first monitoring studies were carried out at the beginning of the project and will be repeated at the end to document changes.

\section{Public Relations}

A major concern of the LIFE Lech project is to inform the local population and interested people. For this purpose, a project homepage (www.life-lech. at) was designed, the River Experience Guide, Tiroler Lech Nature Park was republished, and a folder LIFE LechDynamic River System Lech - Actions for a Wild River Landscape (LIFE Lech - Dynamic River System 2020) was created. The media will be kept up to date on the latest developments and events of the LIFE Lech project. Interested parties can obtain information about the project on the spot at the visitor centre (Naturparkhaus Klimmbrücke), or during excursions. Action days, such as the launch event for the LIFE Lech project or the Riverfest, promote communication and exchange with local people. For all river construction measures, LIFE information boards on site provide details of the project and the objectives of the measures being implemented. From June 2021, a new visitor facility on the Lech in Forchach will provide information about the project. A touring exhibition is currently travelling round Tyrol and has already been a guest in many places, including the seat of the federal government in Innsbruck. Short videos are currently being produced that capture the intentions and results of the LIFE Lech project in attractive and readily comprehensible images. 


\section{Expected results}

The LIFE Lech project aims to promote the river's habitats with their specialized species. To this end, it is expected that around 4.3 ha of forest will be returned to a dynamic river habitat with gravel banks. Along the 12 river-revitalization sections, a total of approximately $11 \mathrm{~km}$ of non-reinforced riverbanks will be created. In addition, about 32 ha of dynamically changing river habitats (FFH Appendix I, Habitats 3220, 3230, 3240) are to be developed. They should contribute to the long-term survival of the unique, highly specialized populations of the Common Sandpiper, Little Ringed Plover and Bryodemella tuberculata grasshopper. For other particularly endangered and protected species, such as the Northern Crested Newt, European Tree Frog (Hyla arborea), Natterjack Toad, Bilek's Azure Maiden, Stone Crayfish, Bullhead or Dwarf Bulrush, two habitats each are to be improved or newly created.

\section{References - further readings}

Braun, V., G. Bendler, A. Haller \& K. Heinrich 2018. Timelines of Tension: Trajectories of Protected-Area Creation in the Austrian Alps. Journal of Alpine Research 106-4. doi: 10.4000/rga.4711

Land Tirol 2020. Archiv Wasserwirtschaft. Available at: www.tirol.gvat/verkehr/baubezirksaemter/bbareutte/archiv-wasserwirtschaft/ (accessed 06/03/2020) [In German]
LIFE Lech - Dynamic River System Lech 2020. Available at: www.life-lech.at (accessed 06/03/2020)

LIFE Lech - Dynamic River System 2016. Projektbeschreibung. [In German]

LIFE Nature and Biodiversity 2016. Technical application forms.

Naturpark Tiroler Lech 2017. Das Naturmagazin "grenzenlose Natur" 5. [In German]

Naturpark Tiroler Lech 2018. Das Naturmagazin "grenzenlose Natur"7. [In German]

Naturpark Tiroler Lech 2019. Das Naturmagazin "grenzenlose Natur" 8. [In German]

Naturpark Tiroler Lech 2019. Fluss-Erlebnisführer Naturpark Tiroler Lech. Amt der Tiroler Landesregierung. [In German]

Naturpark Tiroler Lech 2020. Wanderausstellung LIFE Lech. Amt der Tiroler Landesregierung. In German]

Tiroler Lech - Wild river landscape of the Tiroler Lech. Available at: www.naturpark-tiroler-lech.at/ fileadmin/PDF/Lifeprojekt_Der_Fluss_der_Zeit.pdf (accessed 06/03/2020)

\section{Author}

\section{Marlene Salchner}

is managing director of the Tiroler Lech Nature Park association. www.naturpark-tiroler-lech.at

\section{MIT UNTERSTOTZUNG VON BUND, LAND UND EUROPÄISCHER UNION \\ = Bundesministerium Landwirtschaft, Regionen und Tourismus
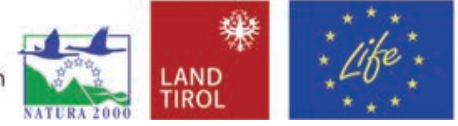 \\ Wasserwirtschaftsamt C. Kempten}

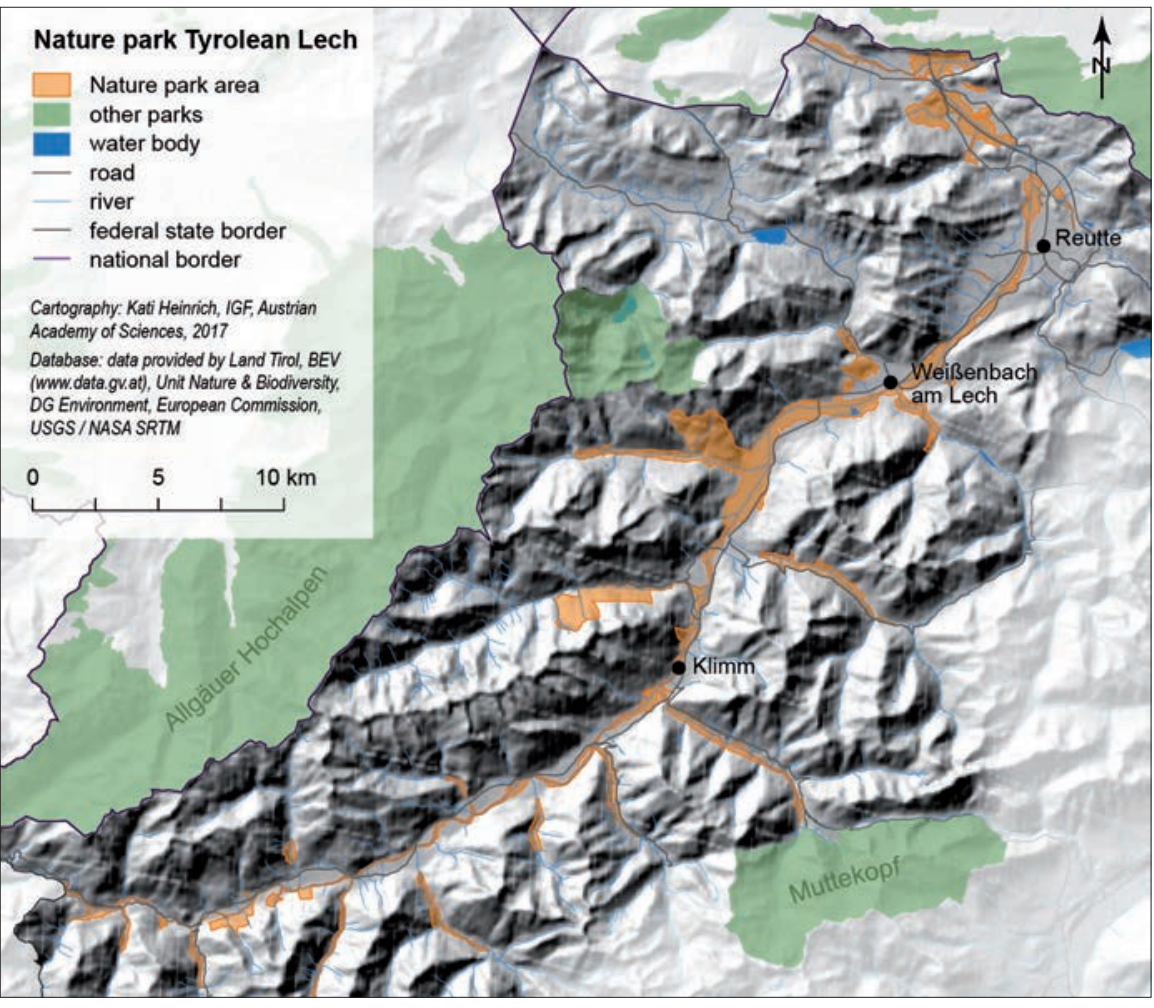

Figure 7 - Tiroler Lech Nature Park (Braun et al. 2018).

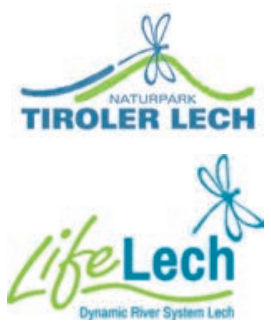

